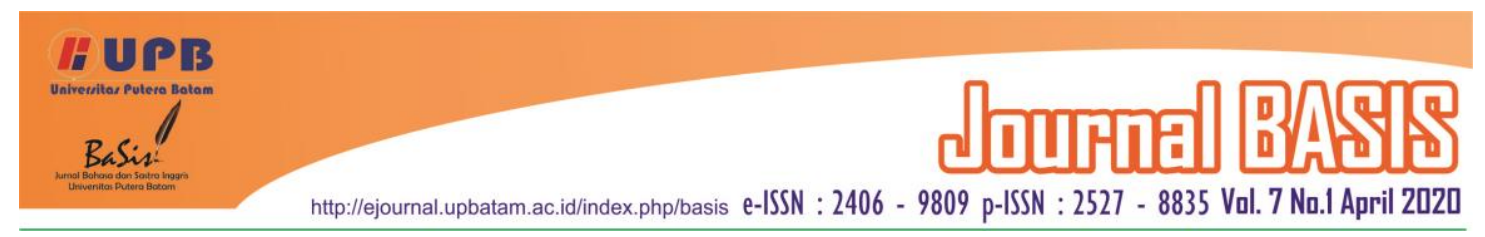

\title{
CULTURAL VALUES OF SOUTH WAKORUMBA COMMUNITY IN NGKAA-NGKAASI FOLKLORE
}

\author{
Fina Amalia Masri ${ }^{1}$ \\ Universitas Halu Oleo, Kendari, Indonesia \\ finaamaliamasri@gmail.com ${ }^{I}$ \\ Wa Ode Halfian ${ }^{2}$ \\ Universitas Halu Oleo, Kendari, Indonesia \\ waodehalfian@gmail.com ${ }^{2}$
}

\begin{abstract}
This paper discussed the cultural values of the South Wakorumba Society in the Ngkaa-ngkaasi folklore. This paper is motivated by the beginning of a reduction in public awareness of the presence of folklore in everyday life. Folklore, which contains a lot of good values, it should stay alive and be preserved in society. On the other hand, the source of the folklore of the elderly people who have mostly died will be increasingly disappeared because these parents may not necessarily pass this story on to their children and grandchildren. So, it is feared that this folklore will become extinct. This paper aimed to describe the cultural values of the South Wakorumba community in the Ngkaa-ngkasi folklore. This paper was analyzed by using qualitative descriptive methods. Data collection techniques used was recording techniques, observation techniques, and interview techniques. The sources of the research data were the elderly people in South Wakorumba sub-district who know the folklore that lives and develops in the community. The results of data analysis showed that there are cultural values of the South Wakorumba community in the Ngkaa-ngkasi folklore, namely cultural values about human relations as individuals (acting calm and unhurried, adding to life knowledge, and fostering personal discipline), cultural values about human relations with humans (please help in kindness, being generous, and deliberation), and cultural values about human relations with nature (utilizing nature).
\end{abstract}

Keywords: cultural value, Ngkaa-ngkaasi Folklore, South Wakorumba Community,

\section{INTRODUCTION}

\subsection{Background}

The existence of folklore is a cultural phenomenon that is universal in people's lives. As a product of public culture, oral literature both types of prose and poetry can be found in almost all places in the world. Oral literature is generally created as a response and the result of the thinking of the social system (Razali, et al., 2000).

Changed in people's mindsets can also lead to their ignorance of Folklore. Folklore is only seen as stories that make no sense and are beyond the reach of common sense. This is certainly a threat to the existence of folklore, if people forget it from their lives.

Folklore as one of the oral literature also has long served as a vehicle for understanding ideas and inheriting values that grow in society. In fact, oral literature for centuries has served as the basis of communication between the creator and the community; it means that based on oral will be more easily digested because of the elements known in society.

Considering the position and role of oral literature which is quite 
Vol. 7 No.I April 2020

e-ISSN : $2406-9809$ p-ISSN : $2527-8835$

http://ejournal.upbatam.ac.id/index.php/basis

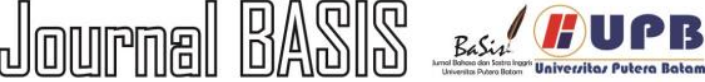

important as mentioned above, so that

only remembered in parts, so that no

oral literature research needs to be done.

Even more so if we remember that the complete story is found. Disclosure of folklore that is not complete or changes in society, such as advances in technology, the presence of mobile phones, televisions, and other technological tools can lead to the gradual loss of oral literature throughout the archipelago. Therefore, oral literary research means to save the oral literature from extinction, which oral literature itself is an attempt to inherit cultural values, because in oral literature there are many values found and ways of life and thinking of people who have oral literature.

Almost every ethnic group in Indonesia recognizes the existence of oral literature, as the South Wakorumba community does. The oral literature of the South Wakorumba community is distributed verbally and is only based on the memory of its speakers, so it is not impossible if the oral literature of the South Wakorumba community experiences has been deviations from its original form. Children prefer watching television or listening to the radio, rather than listening to the tales of their grandparents. The function of grandfather and grandmother as storytellers was replaced by radio and cassette recordings that were widely sold everywhere in Indonesia (Rosidi, 1995).

Folklore is one of oral literature which has cultural values that have been forgotten by the community at this time. Because the source of folklore comes from parents who have mostly died, they will not necessarily pass on to their children and grandchildren. The reality in the field has proven that there are stories with different versions in one village. There is even a story that is unknown as a whole like that is very possible cultural values contained in there will be lost. One of the folklore that reflects the cultural values of the South Wakorumba community is the Ngkaa-ngkaasi folklore.

Ngkaa-ngkaasi is the name of a young man who has been orphaned since he was three years old, so he is taken care of by an elderly grandmother who has no children. At one time, the Ngkaa-ngkaasi asked permission from the old grandmother / caregiver host to go fishing so he gave a mandate to the caregiver's host to guard the garden to avoid pigs. However, the caregiver host is helpless against the pigs that enter the garden and even almost eaten by the pigs. After his return, Ngkaasi-ngkaasi killed all the pigs that were coming to attack the garden. One of the pigs he killed using a spear borrowed from the king. The pig that was hit by the spear was apparently not an ordinary pig, but the son of a pig king who lived in a huge stone pit. Feeling responsible for the spear he borrowed, Ngkaa-ngkaasi then entered into the stone pit to look for the spear that apparently stuck in the pig king's son's back.

After pulling the spear, he recovered from the king's pig son so that the king of the pig gave him gifts. One of gifts was his daughter who had transformed into a human to become his wife. After returning to his home, Ngkaa-ngkaasi told the story of his journey to the caregiver host, the king's spear was taken by the commander or the king's envoy. The second method was carried out by the king by ordering Ngkaa-ngkaasi to catch seven crocodiles, but it was also successfully carried out thanks to the help of his 
wife. The third method was carried out by the king by threatening to kill Ngkaasi-ngkaasi by burning. Feeling threatened, Ngkaa-ngkasi asked his wife for permission to go abroad but was not heeded by his wife. His wife gave a solution by making a mask or statue similar to Ngkaa-ngkasi.

The advice from his wife was immediately implemented by Ngkaangkasi. After the appointed time to kill Ngkaa-ngkaasi arrived, the people also carried Ngkaa-ngkaasi which actually was a statue similar to Ngkaa-ngkaasi. The people threw the statue into a burning fire so the king thought Ngkaangkasi had been consumed by fire. Early in the morning Ngkaa-ngkaasi went to the incinerator and threw himself into the ashes, after which he rose again. The incident was seen by the king's son. Because he was caught when he got up, Ngkaa-ngkaasi was acting like he was from the afterlife. Ngkaangkaasi told his experience to the king that in the hereafter it was a rich country and life there was very pleasant and was picked up lively. The king believes the Ngkaa-ngkaasi story because at that time brought delicious cakes. The king was sure that he was, so he was willing to be burned too to witness the beauty and wealth in the afterlife as witnessed by Ngkaa-ngkasi. The king then ordered his people to burn wood with a high flame. After that, the king ordered to be appointed and thrown into the flame. The fire immediately devoured the king's body. Thus the life history of the king was finished through the tricks of the Ngkaa-ngkaasi.

Based on the background above, the problem in this paper is "what is the the cultural values of the South Wakorumba community described in the Ngkaa-ngkaasi folklore?". Therefore, this paper aimed to describe the cultural values of the South Wakorumba community in the Ngkaangkaasi folklore.

\section{THEORETICAL REVIEW}

2.1 Cultural Values

Cultural values in human relations with the community are values related to the interests of community members, not values that are considered important in one community member as an individual, as a person. individuals try to assess the values that exist in society because he asks to group themselves with existing community members, who are very concerned with the common interests rather than self interests. Cultural values are values that exist and develop in society. Koentjaraningrat (1984) argues that cultural values are the first level of ideal or custom culture. Cultural values are the most abstract layers and broad scope. So, cultural value is something that is considered very influential and used as a guide for a society.

Furthermore coentjaraningrat (in Djamaris, 1996) suggests a system of cultural values consisting of conceptions that live in the minds of most of the citizens of the community regarding things that they must consider very valuable in life. Therefore, a cultural value system usually functions as the highest guideline for human behavior. Human behavior system is more concrete level, such as special rules, laws, and cultural values. Values and systems that live and are adhered to by a particular ethnic group are traditional cultural values.

A cultural system consists of conceptions that live in the minds of most members of the community, regarding things they must consider valuable in life, (Esten, Ed.tt: 1). According to Kluchon (in 
coentjaraningrat, 1985), all cultural value systems in all cultures are related to five main problems in human life, namely: 1) Problems regarding the nature of human life, 2) problems concerning the nature of human work, 3) problems regarding the nature of human position in space and time, 4) the problem of the nature of human relations with the natural surroundings, and 5) the problem of the nature of human relations with each other.

Furthermore, stated by Djamaris (1993), a fundamental problem in cultural life is the conflict that arises due to the relationship between humans and themselves, humans with other humans, humans with nature, and human relationships with God. In fact the disturbed humans will pour their thoughts into cultural works. Therefore, this human behavior demands responsibility for culture which will be part of human life itself. The accountability of human behavior will all be related to the obligations that must be done by a human being in living his life as a personal being, a social being and a cultural being. In terms of cultural values as an abstract about the basic problems in human life that are very important, these obligations are reflected in morals or morality. Morals or moralities are something that is considered in accordance with commonly accepted ideas about human actions, which are good and reasonable. So, it is in accordance with measures generally accepted by actions that include certain social or environmental unity (Ya'qub, 1983: 14). Thus, Indonesian cultural values are generally based on the Islamic view.

In his book entitled Islamic Ethics, Ya'qub (1983) groups four categories of cultural values as follows: a. Cultural Values in Human

Relations with Himself In the relationship of moral obligations to himself, Ya'qub (1983: 138-140) mentions cultural values, among others, as follows (1) Maintaining personal purity both physically and spiritually, (2) Maintaining tidiness of self; tidiness factor as a manifestation of personal discipline and personal harmony, (3) Be calm and not rush, (4) Increase knowledge; life is full of struggles and difficulties, (5) Fostering personal discipline; one of the obligations to oneself is to forge oneself, train yourself for personal discipline. Personal discipline requires good qualities and attitudes accompanied by patience, perseverance, craft, loyalty, perseverance, etc., the nature of personal coaching.

b. Cultural Values in Human Relations with Human Fellow In moral obligations to each other, the cultural values are as follows; (1) Please help in kindness, (2) can be trusted; words and actions are always trustworthy, (3) do not persecute, act injustice and prevent persecution, (4) peace, prioritizing peaceful attitudes, (5) generous, giving to others, (6) fair, towards whoever and whenever they are fair, (7) Wise, not rigid in carrying out the provisions, (8) Forgiving, like to forgive others, (9) Deliberation, like to negotiate problems, (10) Tolerance, tension in doing actions concerning other people.

c. Cultural Values in Human Relations with Nature

Nature builds and colors human thought patterns. Kluckhohn (in Koentjaraningrat, 1990) revealed 
that the orientation of cultural values in human relations with nature is divided into three groups. There is a cultural value which is seen as something so terrible that humans can in fact only give up without being able to do much. There is also a culture-oriented value that sees nature as something that can be resisted by humans, and requires humans to always try to conquer nature. Furthermore there is also a culture oriented value that humans try to maintain harmony with nature.

In the relationship of moral obligations to nature, cultural values include the following; (1) Utilizing nature, nature as a source of life that stores wealth for human use. Humans process nature for their survival, (2) Do not damage nature, between humans and nature, a relationship is established. Humans adjust themselves to nature for their own interests, (3) Love nature, nature as a means of humans to serve and serve God Almighty. The beauty of nature makes human piety to realize the greatness of its Creator, Allah. Humans are not able to make natural imitations to match his beauty.

d. Cultural Values in Human Relations with God

\subsection{Folklore}

The importance of studying the values contained in folklore, because folklore has a cultural function. The birth of folklore is not solely driven by the desire of the speaker to entertain his people but with great patience he wants to convey noble values to the next generation. This is in line with the opinion expressed by Djamaris (1993: 15) which says that folklore is a group of stories that live and develop for generations from one generation of the next generation. Called folklore because this story lives among the people and almost all walks of life know it. Folklore belongs to the people not to someone. Folklore is usually told verbally by storytellers who memorize the storyline. That is why folklore is called oral literature. The story is told by storytellers while sitting somewhere to anyone, children and adults (Djamaris, 1993: 6).

According to Danandjaya (1996: 16) folklore is part of an oral folklore that is pure folklore. Whereas the understanding of folklore is part of the culture of any kind of collective, traditionally in a different version that in oral form or example accompanied by gesture gestures or reminder aids. On the other hand, Andre (1981: 1) put forward the understanding and function of folklore in his book titled "Literary Oral Literature" as follows: folklore is a culture that grows and develops in the midst of that society which is inherited verbally as a shared property. Folklore not only functions as a means of entertainment, leisure time and channeling feelings for speakers and listeners, but also as a reflection of group attitudes and dreams, educational tools, means of ratifying institutions, and cultural institutions and maintenance of community norms.

Rosidi (1995: 15) states that literature written in regional languages found throughout the archipelago that is called Nusantara literature. While the so-called Indonesian literature, is only literature written in Indonesian. So because of the consideration in terms of language, in Indonesia we are familiar with regional literature (Nusantara literature), foreign literature, and Indonesian literature. Meanwhile, according to Gafar (1990: 3) folklore is 
one form of oral tradition that uses language media. This understanding will be blurred when confronted with a form of oral literature that also uses language media such as puzzles and expressions. Therefore, folklore is part of literary works in the form of fairy tales or other forms of story that develop among certain communities and are disseminated orally using their respective regional languages. The birth of folklore due to the complex interplay of socio-cultural factors and folklore contains thoughts about the values that must become role models of the people concerned in managing daily actions.

\subsection{PREVIOUS STUDY}

There are some researches about cultural values, first is written by (Rukesi \& Sunoto, 2017) entitled Nilai Budaya dalam Mantra Bercocok Tanam Padi di Desa Ronggo, Kecamatan Jaken, Kabupaten Pati, Jawa Tengah: Kajian Fungsi Sastra. This research found that there is cultural values in spells of rice plant planting which is seen from the pattern of human relationship, that is cultural values in the relationship between human and God consists of six forms, cultural values in relatioship between human and nature consists of four forms, and cultural values in relationship between human and other human consists of one form.

Another article that discussing about cultural value is written by (Simanjuntak, 2015). In his article simanjutak discussed the application of the modern anthropolinguistics (competence, performance, indexicality, and participation) in Umpasa of Batak Toba culture. The linguistic anthropology examines the structure and relationships through kinship term, the concept of color, parenting, or examine how community members communicate with each other in certain situations such us the costum ceremonies, then connects it with the culture's concept

The last article is written by Arianto \& Simanjuntak (2019) about one of malay cultural wisdom and focklore intepretaion in Batam. They suspected thar there is a paradoxical narrative behind Mak Ungkai character in malay focklore which is relatively close to nature, preserves the environment, and counter-patriarch. The result of their research explained that (1) the existence of patriarchal stereotypes through mak ungkai sea ghost story (2) the paradoxical representation of women based on ecofeminist framework behind the story.

All of the article above discussed about cultural value in literary work, language, or foclore but it is different with the phenomena discussed in this paper. This paper focused on the cultural values of the South Wakorumba Society in the Ngkaa-ngkaasi folklore.

\section{RESEARCH METHODOLOGY}

\subsection{Research Type}

This research used descriptive qualitative method. According to Moleong (1995), descriptive qualitative research is described as the qualitative research, a kind of research which does not include any calculating or enumerating, wherein descriptive qualitative research seeks to provide pictures by using data in the form of words or pictures in preference to numbers. This study also used several instruments, namely: 1) tape recorder to record folklore used as research data, 2) camera to take pictures related to the story used as research data, and 3) 
Vol. 7 No.1 April 2020

e-ISSN : $2406-9809$ p-ISSN : $2527-8835$

http://ejournal.upbatam.ac.id/index.php/basis

ป回的回|

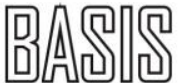

Basin (IF) UP

recording sheet used to complete story about the traditions or habits of the data recorded folk.

local community.

\subsection{Source of Data}

The data used as research material was Ngkaa-ngkaasi folklore which has been known orally for generations by the South Wakorumba community. The source of the research data was five elderly people in South Wakorumba sub-district who know the Ngkaa-ngkaasi folklore that lives and develops in the community. The data was recorded, noted down, collected and then analyzed.

\subsection{Techniques of Data Collection}

Techniques of data collection are a method used by researchers to collect data of research (Maryaeni, 2005). The collection of oral literary data can begin with the recording step. Recording as far as possible should be carried out in the context of original oral literature. It means that the oral literature is being sung or told and researchers are recording directly (Endraswara, 2003).

Because this research is a field research, the researcher collected the data directly to the research location. The techniques used were:

1. The recording technique was used here because the researcher intended to collect folklore in the form of oral literature. Thus, the results of the recording were transcribed into Indonesian so that they become written material.

2. Observation technique was carried out to observe the culture that exists in the South Wakorumba community.

3. Interview technique was carried out, both for the storyteller and for community leaders who are deemed appropriate to provide information

3.4 Techniques of Data Analysis

From the data collected, it was then analyzed by using the following procedure:

a. Selection

Selecting data that was really needed, namely data that provided information about the culture of the South Wakorumba community and Ngkaa-ngkaasi folklore and discards unnecessary data or the data inwhich did not provide information about the culture of the South Wakorumba community and Ngkaa-ngkaasi folklore.

b. Transcription

After the data was selected, then Ngkaa-ngkaasi folklore data was transcribed from spoken language into written language using Latin letters.

c. Translation

After the Ngkaa-ngkaasi folklore data was transcribed, it was then translated in Indonesian with using free translation.

d. Described the storytelling environment, which was the environment of South Wakorumba subdistrict.

e. Analyzing the cultural values of the South Wakorumba community contained in the Ngkaa-ngkaasi folklore.

f. Discussing the results of the cultural values of the South Wakorumba community contained in the Ngkaangkaasi folklore.

g. Making conclusions and suggestions.

\section{RESULTS AND DISCUSSION}

4.1 Cultural Value of South

Wakorumba Community in Ngkaangkaasi Folklore

4.1.1 Cultural Values about Human 
Vol. 7 No.1 April 2020

Relationships as Persons

4.1.1.1. Be calm and not rush

In doing something, humans should not be in a hurry. Everything must be considered carefully and not quickly carried away by lust. We must think first of the pros and cons, the importance or not, the benefits or mudhoratnya. In the folklore "Ngkaangkaasi", there are some values of human culture as a person in this case, apply calm and not in a hurry. That can be seen in the quote below.

(1) "Before the order was carried out, he first conveyed to his wife. According to his wife, this job is an easy job, therefore there is no need for it to be difficult ".

(2) "The king still threatened to kill Ngkaa-ngkaasi, so that it would not be possible for him to live again. For him there is no other way anymore. Therefore he asked permission from his wife to go abroad. His request was not granted by his wife, with consideration, that according to his wife there was still a way to live, to overcome the threat from the king. By making a mask or statue that is similar to Ngkaangkaasi".

(3) "Ngkaa-ngkaasi began to stand tall and tell his false experience, as if he were from the hereafter. According to Ngkaa-ngkaasi that the hereafter is a country that is rich and life there is very pleasant. Added to that, when people die they will be picked up with happiness ".

In data one, it is said that the wife of Ngkaa-ngkaasi remained calm when her husband, Ngkaa-ngkaasi got the task from the king to catch seven crocodiles. While the data two also, his wife remained calm when her husband asked permission to go abroad because he felt his life was uncomfortable because of threats from the king. His wife advised her husband to make a statue similar to him. The statue will be burned by the king to replace Ngkaa ngkaasi, while data three is told that Ngkaa ngkaasi calmly tells his fake experiences about his visit in the hereafter, so that the king believes and wants to be burned as well as Ngkaangkaasi in order to feel pleasure like which was divorced by Ngkaa-ngkaasi. That way the tyrant king can be removed and his life with his wife and caregiver host becomes happy.

From the three excerpts above, it can be seen that the calm and unhurried attitude of Ngka-ngkaasi's wife can save her husband's life and can trap the unjust king, so he wants to burn himself. Because the king is no longer present, their lives will be happy.

\subsubsection{Add Life Knowledge}

Humans are basically creatures who always want to know and try something new. In undergoing and trying new things, we are faced with many trials and difficulties of life. But with these trials and difficulties, we become better human beings. In the folklore "Ngkaa-ngkaasi" there are several values of human culture as a person in this case, adding knowledge of life. This can be seen in the quote below.

(4) "On their way they have difficulty, because the hole they have passed has been closed. The way to penetrate the hole must go through the footbridge. With great care, they walk over the footpath and finally penetrate in this world". 
In the passage of the story above it is stated that when they were about to return to their villages, Ngkaa-ngkaasi and his wife experienced difficulties, namely the holes that Ngka-Ngkaasi had passed had been closed so that they had to pass through a footbridge to penetrate into this world. With great caution, they were finally able to pass the catwalk and get to their house.

\subsubsection{Fostering Personal Discipline}

One form of coaching towards oneself is forging oneself, training oneself to be able to have personal discipline. Personal discipline requires praiseworthy traits and attitudes accompanied by patience, perseverance, craft, loyalty, steadfast, etc. In folklore "Ngkaa-ngkaasi" there are several values of human culture as a person in this case, fostering personal discipline. This can be seen in the quote below.

(4) "Now, trying to find the spear everywhere. After a few days of walking, there arrived in a garden whose plants have also been consumed by pigs. He began to pay attention to the garden while looking for pigs with spears". In the passage of the story above it is mentioned that Ngkaangkaasi is still searching for the missing king's spear diligently. This can be seen in the excerpt of the story above. He never looked for the spear anywhere. He never gave up until finally he could find and get the spear back even though he had to take a lot of danger during his journey".

\subsubsection{Cultural Values about Human}

Relations with Humans

4.1.2.1 Giving Help in Kindness
Basically, humans are social

beings who cannot live alone without the help of others. Humans always need help from others in their lives. No matter how rich the person is, he still needs others in his daily life. Mutual cooperation is one aspect of the value of helping to help in goodness. Helping in goodness is one of the cultural values included in human relations with each other. This can be seen in the quote below.

(6) "At the age of three, Ngkaangkaasi is among the unfortunate children. $\mathrm{He}$ has never felt love from his parents. From childhood to adulthood he was raised by an old grandmother. Incidentally the old grandmother did not have offspring. Thus the old grandmother was very fond of her ".

In the passage of the story above it is mentioned that Ngkaa-ngkaasi has been an orphan since she was three years old. He was only raised by an elderly grandmother who had no children. The grandmother was very fond of Ngkaa-ngkaasi. The old grandmother still loved Ngkaa-ngkaasi although Ngkaa-ngkaasi was not her biological child.

\subsubsection{Be Generous}

Generosity is one of the attitudes contained in the cultural values associated with humans with each other. In the folklore "Ngka-ngkaasi" there are several cultural values in human relationships with others. This can be seen in the quote below.

(7) "Seven days later, after the spear was removed the king's son recovered. In the beginning. All the royal family was very happy with 
the recovery of his son. Therefore, in return, given a valuable gift. After receiving the gift, after receiving the gift, asking for a request to go home to the village Apparently the king has not let him go because his gift has not been worth his services, namely healing his son. one of his daughters to be his wife ".

In the excerpt of the story above it is mentioned that the king of pigs, gave a gift to Fuck because of his services to treat his sick son. Then the king ordered Failing to choose one of his daughters to be his wife. to represent his gratitude for the services of $\mathrm{Ngkaa}$ ngkaasi. The data in the two data also shows the generous attitude of the pig king.

\subsubsection{Deliberation}

Deliberation is a joint discussion with the intention of reaching a decision or solving a joint problem. Deliberation is one of the cultural values contained in human relationships with others. In Ngkaa-ngka folklore there are several cultural values in human relations with each other. This can be seen in the quotation below.

(8) "The task was felt very heavy by Ngkaa-ngkaasi. He said that to his wife, according to his wife, the task was not heavy as long as he followed the instructions and followed by good intentions, it would surely succeed.

(9) "Before the command was carried out, he first conveyed to his wife. According to his wife, this job is an easy job, therefore there is no need for it to be difficult ".

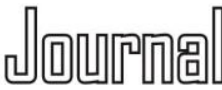

(10) "The king still threatened to kill Ngkaa ngkaasi, so that it would not be possible for him to live again. For him there is no other way anymore. Therefore he asked permission from his wife to go abroad. His request was not granted by his wife, with consideration, that according to his wife there was still a way to live, to overcome the threat from the king. By making a mask or statue similar to Ngkaa-ngkaasi ".

In the data eight to nine it is said that, Ngkaa-ngkaasi always discusses all the difficulties he experienced because of the tyrannical attitude of the king to his wife before doing anything. Because discussing everything with his wife, the first task considered difficult by Ngkaa-ngkaasi finally can be carried out. This can be seen in data eight to nine data. In the tenth data also, it was mentioned that Ngkaa-ngkaasi asked his wife's permission to go overseas because he could no longer face the king's arbitrary attitude towards him. But his wife did not allow it, because there are ways that can be done to avoid threats from the king. Thanks to the advice from his wife, then Ngkaangkaasi can escape from the threat of the king, even he can fool the king so that the king wants to be burned. After the death of the king, Ngkaa-ngkaasi lived happily together with his wife and caregiver host.

\subsubsection{Cultural Values about Human \\ Relations with Nature}

\subsubsection{Make Use of Nature}

Nature as a source of human life that stores wealth for human use. Humans process it for survival. In the "Ngkaa-ngkaasi" folklore there are 
several cultural values in the human relationship with nature. This can be seen in the quote below

(11) "At one time the Ngkaangkaasi asked permission from the caregiver's host to go fishing. The request was granted by the grandmother. Before leaving, he left a message for the caregiver's host, namely regarding the care of the garden ".

(12) "His wife helped search for buffalo in the forest. After they arrived in the middle of the forest, his wife looked around him, then faced one direction and shouted loudly. The voice seemed to be a special call for buffalo. Not long after that appeared a swarm of buffaloes. The buffalo that emerge are easily captured by them ".

In the data eleven it is said that Ngkaa-ngkaasi, asking for permission to go fishing, before leaving, he entrusts the care of his garden to the caregiver's host. In this case Ngkaaa-ngkaasi use land as land for gardening in order to make ends meet. In data twelve it is said that Ngkaangkaasi's wife went to the forest to look for the buffalo that the king ordered her husband to do. In this case, Ngkaangkaasi and his wife used the forest to find and catch the buffalo that the king requested.

\section{CONCLUSION}

\subsection{Conclusion}

The folklore of the South Wakorumba community contains cultural values concerning human relations as a personal self (acting calm and unhurried, increasing life knowledge, and fostering personal discipline), human relations with fellow human beings (helping in kindness, being generous, being fair to others, wise, forgiving, deliberation, and tolerance), the relationship between humans and nature (utilizing nature), and the relationship between humans and their Lord (arajak and prayer). So the folktales of the South Wakorumba community contain various cultural values.

5.2 Suggestions

The results of research in the form of cultural values in folklore can be used as a reference in daily activities or for practical purposes in social interaction.

\section{REFERENCES}

Arianto, T., \& Simanjuntak, D. S. (2019). Paradoxical Representation of Female Narration in the Spirit of Mak Ungkai Story. Journal BASIS, 6(2), 173-184. https://doi.org/https://doi.org/10.33 884/basisupb.v6i2.1413

Danandjaya, James, 1986. Folklore Indonesia. Jakarta: Pustaka Utama Graffiti.

Djamaris, Edward. 1993. Menggali Khasanah Sastra Melayu Klasik. Jakarta: Balai Pustaka.

Endraswara, Suwardi. 2003. Metodologi Penelitian Sastra. Yogyakarta: Med Press.

Esten M. 1999. Kajian Transformasi Budaya. Jakarta: Balai Pustaka

Esten, Mursal.2000. Kesusastraan Pengantar Teori dan Sejarah. Bandung: Sinar Baru Algesindo. 
Vol. 7 No.1 April 2020

e-ISSN : 2406 - 9809 p-ISSN : $2527-8835$

http://ejournal.upbatam.ac.id/index.php/basis

Frese, Michael. 2015. Cultural Practices, Norms, and Values. Journal of Cross Cultural Psychology, 46 (10), 1327-1330. https://journals.sagepub.com/doi /10.1177/0022022115600267

Gafar, Zainal Abidin. 1991. Struktur Sastra Lisan Serawi. Jakarta: Depdikbud.

Hendrayani, Eulis. 2003. "Kajian Nilai Budaya dalam Buku Kumpulan Puisi Karya Rendra" (Tinjaun Deskriptif-Analisis terhadap Puisi-puisi Karya Rendra untuk Kepentingan Penyusunan Model Bahan Pembelajaran Puisi di SMA). Bandung: Tesis UPI tidak Diterbitkan.

Koentjaraningrat, 1990. Kebudayaan, Mentalitas dan Pembangunan. Jakarta: Gramedia.

Maryaeni. 2005. Metode Penelitian Kebudayaan. Malang: Bumi Aksara.

Moleong. J. Lexy. 1995. Metodologi Penelitian Kualitatif. Bandung: PT. Remaja Rosdakarya.

Nurgiantoro, Burhan. 2007. Teori Pengkajian Fiksi. Yogyakarta: Gajah Mada University Press.

Ratna, Nyoman Kutha. 2008. Teori, Metode, dan Teknik Penelitian Sastra. Yogyakarta: Pustaka Pelajar.

Rosidi, Ajib. 1995. Sastra dan Budaya ke Daerahan dalam Ke Indonesian. Jakarta: Pustaka Jaya.

Rosidi, Ajib. 1997. Pembinaan Minat Baca Apresiasi dan Penelitian

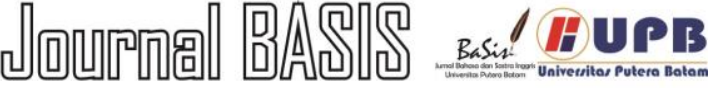
Sastra. Jakarta: Panitia Tahun Buku Internasional.

Rukesi, R., \& Sunoto, S. (2017). Nilai Budaya dalam Mantra Bercocok Tanam Padi di Desa Ronggo, Kecamatan Jaken, Kabupaten Pati, Jawa Tengah: Kajian Fungsi Sastra. Indonesian Language, Literature, and Learning Journal, 1(1), 25-45. https://doi.org/http://dx.doi.org/10. 17977/um007v1i12017p025

Rusyana, Yus. 1982. Metode Pengajaran Sastra. Bandung: CV Gunung Larang.

Saini K.M dan Sumardjo, Jakob.1986. Apresiasi Kesusastraan. Jakarta: Gramedia.

Sayuti, A. Suminto.1996. Apresiasi Prosa Fiksi. Jakarta: Departemen Pendidikan dan Kebudayaan.

Semi,Atar.1998. Anatomi Sastra. Padang: Angkasa Raya.

Simanjuntak, D. S. (2015). Penerapan Teori Antropolinguistik Modern (Competence, Performance, Indexicality, \& Partisipation) dalam Umpasa Budaya Batak Toba. Jurnal Basis, 2(2), 71-78. http://ejournal.upbatam.ac.id/index .php/basis/article/view/407

Sikki, Muhamad. 1986. Struktur Sastra Lisan Toraja. Jakarta: Depdikbud.

Wellek, R dan Warren, A, 1995. Theory of Literature (translated by Melanni Budianta). Jakarta : Gramedia.

Ya'qub, Hamzah. 1983. Etika Islam. Bandung: Dipanegoro 